\title{
Diagnosis of Brazilian vesiculoviruses by reverse transcription- polymerase chain reaction
}

\section{Daniela Wey Bonutti, Luiz Tadeu Moraes Figueiredo}

Centro de Pesquisa em Virologia, Faculdade de Medicina de Ribeirão Preto, Universidade de São Paulo, Av. Bandeirantes 3900 , 14049-000 Ribeirão Preto, SP, Brasil

We describe a reverse transcription-polymerase chain reaction (RT-PCR) and a nested-PCR for diagnosis of Piry, Carajás, Cocal, and Alagoas vesiculoviruses from Brazil. The RNA extracts of viral and clinical samples were submitted to a RT-PCR using Vesiculovirus $G$ primers that amplify part of the glycoprotein gene. The RT-PCR produced amplicons of expected size, 290 base pair, for the four studied viruses. The RT-PCR showed a high sensitivity being 151.3 times $(2.18 \mathrm{log})$ more sensitive for the detection of Piry virus than the classical procedure for virus detection in tissue culture based on the viral cytophatic effect. Amplicons had nucleotides sequenced and were aligned in order to select internal primers for a nested-PCR to confirm the origin of Piry, Carajás, Cocal, and Alagoas Vesiculovirus. Ten blood and tarsal pad epithelial samples of infected Guinea-pigs had Vesiculovirus genome amplified by RT-nested-PCR.

Key words: Vesiculovirus - vesicular stomatitis virus - reverse transcription-polymerase chain reaction - diagnosis nested-PCR - Brazil

Piry, Carajás, Indiana 2-Cocal, and Indiana 3-Alagoas viruses comprises the genus Vesiculovirus of the family Rhabdoviridae. The Vesiculovirus are bullet-shaped 150$180 \mathrm{~nm}$ long enveloped viruses. The virus envelope has spikes that are composed by a glycoprotein $(\mathrm{G}) . \mathrm{G}$, having $\sim 1670$ nucleotide (nt), has the main antigenic determinants of the Vesiculovirus and induces neutralizing antibodies in infected animals (Robert \& Rose 1996). The viral nucleocapsid contains RNA that is wrapped by a protein $(\mathrm{N})$ to form the helical ribonucleoprotein (RNP). The nucleocapsid also includes two minor non-structural proteins, $\mathrm{L}$ and NS, that act as viral polymerases. The $\sim 11161 \mathrm{nt}$ RNA of Vesiculovirus is single-stranded and negative polarity, having $50 \mathrm{nt}$ in the 3 ' non-coding region and $60 \mathrm{nt}$ in the 5 'non-coding region. At the RNA, each coded gene includes a poly A tail at the end (Robert \& Rose 1996).

There are a number of strains of virus identified as Vesiculovirus (New Jersey and Indiana serotypes, Isfahan, Chandipura and Piry). Indiana serotype is divided into three separate serological groups (Federer et al. 1967, Bilsel $\&$ Nichol 1990). Indiana 1 , for the classical strains and sub-types Indiana 2 for the Cocal, viruses recovered from mites collected from rice rats trapped in Bush Bush Forest, Trinidad (Jonkers et al. 1964) and also near Belém, Pará, Brazil (RE Shope, cited by Federer et al. 1967) and subsequently from outbreak of Vesicular Stomatitis (VS) occurred in Salto, Argentina (Pirazzi et al. 1963) and in Rancharia and others cities from the state of São Paulo, Brazil, and sub-type Indiana 3 for the Alagoas, Brazil, virus (Federer et al. 1967, Andrade 1974). The VS viruses (Indiana 2 and Indiana 3), are related, more distantly, to

Corresponding author. E-mail ltmfigue@fmrp.usp.br Received 25 August 2004

Accepted 14 March 2005 the classic serotypes Indiana 1, but quite distinct from the other serotype, New Jersey (Federer et al. 1967).

Other Brazilian Vesiculovirus such as Marabá and Carajás belong to the Indiana serotype (Travassos da Rosa et al. 1984). The Brazilian virus Jurona is ungrouped in the Indiana serotype (Murphy et al. 1995).

Vesiculovirus infection of animals and plants occur worldwide. New Jersey and Indiana 1, Indiana 2-Cocal and Indiana 3-Alagoas viruses are important for veterinarian public health because they are the causal agent of VS, a vesicular disease of equines, pigs, and cattles, clinically similar to Foot-and-mouth disease (FMD). Thus, VS in pig must be distinguished serologically from FMD, Swine vesicular disease (SVD) and Exanthema vesicular (EV), as well in cattle, the disease must be distinguished from FMD. Besides, Piry, Chandipura, and Isfahan viruses produce human acute febrile illness and meningoencephalitis (Bhatt et al.1967, Tesh et al. 1977, Wilks et al. 1984).

The diagnosis of vesiculoviruses is usually done by serology using the neutralization and complement fixation tests for detection of virus-specific antibodies. Immunoenzymatic and immunofluorescent methods are used for detecting IgM antibodies related to recent infection (Fernandez 1988). Vesiculovirus isolation is difficult in human infection because virus may be present in quantities too small to be detected and still be infective. In a study with 32 individuals presenting VS by New Jersey virus, the virus was isolated from none. Clinical samples obtained after human accidental infection also did not permit Piry virus isolation (Tavares Neto 1992). On the other hand, animal VS lesions are rich in virus particles and the virus can be easily isolated after inoculation in tissue culture or in newborn-mice (Arbeláez 1983, Karabatsos 1985, Fernandez 1986). However, the identification of Vesiculovirus isolated virus by complement fixation or other serological tests is laborious. Classically, complement fixation and neutralization cross tests including different viruses serotypes, sub-types and the new 
isolate are performed (Tavares Neto 1992). Monoclonal antibodies for use in immunofluorescent and immunoenzymatic tests have been also used (Vernon et al. 1985). The detection of VS virus antigens in clinical samples using enzyme-immunoassay was successfully tested for New Jersey and Indiana-1 viruses (Fernandez 1988).

The RT-PCR was tested for diagnosis of New Jersey virus in clinical samples of sick animals and the nucleotide sequence of the amplicons allowed a phylogenetic study of these viruses (Rodriguez et al. 1993). ART-PCR was also used in pigs for elucidating the differential diagnosis of VS, FMD, Exantema Vesicular (EV) and Swine Vesicular Disease (SVD) (Nunez et al. 1998). In this paper, we show the development of a RT-PCR and a nested-PCR for diagnosis of four Brazilian vesiculoviruses (Carajás, Piry, Indiana 2-Cocal/Registro and Indiana 3-Alagoas).

\section{MATERIALS AND METHODS}

The viruses - Four Brazilian vesiculoviruses Piry, Carajás, Cocal, and Alagoas were tested in the study. Piry virus Bean 41191 and Carajás virus BeAn 411459 were kindly supplied by Dr Pedro Fernandes Vasconcelos from the Evandro Chagas Institute in Belém, Brazil. Alagoas virus Bn/64 was kindly supplied by Dr Cláudio Andrade from the School of Veterinarian of the Federal Fluminense University, Niteroi, Brazil and Cocal virus Registro/SP was kindly supplied by Dr Aramis Augusto Pinto from the School of Agrarian and Veterinarian Sciences of the University of State of São Paulo, Jaboticabal, Brazil.

Suspensions of the studied viruses were obtained from macerated brains of infected baby-mice and from supernatant fluid of C6/36 (Aedes albopictus) tissue culture, after confirmation by immunofluorescent test using mouse immune ascitic fluids (Figueiredo 1990). Clinical materials including 5 blood samples and 5 skin tarsal pad epithelial samples of guinea pigs infected with Indiana 3-Alagoas virus were also analyzed. The RNA was extracted from the virus suspensions and clinical samples using the Qiamp DNA Blood Mini Kit (Qiagen, US).

$R T-P C R$ - Primers for use in the RT-PCR were selected from high homology regions of the G gene of Piry (GenbankD26175), New Jersey (GenbankAF170602), Indiana 1 (GenbankX03633), Indiana 2-Cocal (GenbankAF045556) and Chandipura (GenbankJ04350) viruses after align their nucleotide sequences using the software DNAsis (Hitachi, Japan, 1995). Thus, Vesiculovirus G complementary (5'-CAGATGGTAT GGACCCAAATA-3') and sense (5'-CCACACCGATGAATTGTGGAC-3') primers were selected.

The RT and the PCR were carried out in the same tube. The reaction mixture included $5 \mu 1$ RNA extracts, $0.3 \mathrm{mM}$ Vesiculovirus $\mathrm{G}$ reverse primer, $0.1 \mathrm{mM}$ dNTPs, $10 \mathrm{U}$ de inibidor de RNAase (Pharmacia, US), 10 U reverse transcriptase (Pharmacia, US), and $2.1 \mu$ lof the corresponding $5 \times$ buffer in a final volume of $13 \mathrm{ml}$. The reaction mixture was incubated at $41^{\circ} \mathrm{C}$ for $1 \mathrm{~h}$. The PCR mixture included $1 \mathrm{U}$ of Taq DNA polymerase (Pharmacia, US), $4 \mu \mathrm{l}$ of the corresponding $10 \times$ buffer, $0.3 \mu \mathrm{M}$ of sense and reverse primers in a final volume of $50 \mu \mathrm{l}$ completed with DEPC treated water. Forty cycles were carried out at $93^{\circ} \mathrm{C}$ for $90 \mathrm{~s}, 50^{\circ} \mathrm{C}$ for $2 \mathrm{~min}$ and $72^{\circ} \mathrm{C}$ for $4 \mathrm{~min}$ (Rodriguez et al. 1993).

Selection of primers for the nested-PCR - The amplicons obtained by the RT-PCR were purified using the PCR purification Kit (Qiagen, US) and submitted to the Thermo Sequenase CY5.5 terminator kit (Amersham, England) also including the Vesiculovirus $\mathrm{G}$ complementary primer. Reaction products were submitted to eletrocrophoresis in a $6 \%$ polyacrilamide gel, inside of the Personal seq $4 \times 4$ (Pharmacia, US) machine following manufacturer's recommendations. These amplicon nucleotide sequences of Piry, Indiana 3-Alagoas and Carajás viruses were aligned in order to confirm their viral origin based on the high homology with Vesiculovirus previously known sequences. The amplicon nucleotide sequences of Piry, Indiana 3-Alagoas, and Carajás viruses were also aligned in order to select internal primers from high homology regions for a nested-PCR. Thus, Piry complementary (5' CATCTGAGACCGACAACATC3') and sense (5'TCACTTGGACCAACATTGCC3') primers were selected.

Nested-PCR - The nested-PCR was used for confirmation of the Vesiculovirus origin of amplicons obtained by RT-PCR. The reaction mixture contained $1 \mu l$ of the RTPCR amplicon, 1U of Taq DNA polymerase (Pharmacia, US), $5 \mu$ l of buffer $10 \times, 0.3 \mathrm{mM}$ of Piry primers in a total volume of $50 \mu \mathrm{l}$. Thirty five cycles were performed at $93^{\circ} \mathrm{C}$ for $90 \mathrm{~s}, 50^{\circ} \mathrm{C}$ for $2 \mathrm{~min}$ and $72^{\circ} \mathrm{C}$ for $2 \mathrm{~min}$.

Amplicons obtained by RT-PCR and nested-PCR were submitted to an eletrocrophoresis in $1.7 \%$ agarose gel stained with ethidium bromide, visualized under UV light. These sizes of the amplicons were determined by comparison with a $100 \mathrm{bp}$ DNA ladder (Promega, US).

Sensitivity determination of the RT-PCR - The sensitivity of the RT-PCR was determined by comparing the Vesiculovirus amplicon detection with a method in Vero E6 (green monkey kidney) cell cultures based on the detection of cytopathic effect $24 \mathrm{~h}$ after viral infection. Tenfold dilutions of the Piry virus seed were used to infect 8 microplate wells $(50 \mathrm{ml} /$ well) containing Vero E- 6 cell monolayers. The TCID50/ml titer of Piry virus was measured by the Reed-Muench method (Reed \& Müench 1938). The tenfold dilutions of Piry virus had the RNA extracted (140 $\mu \mathrm{l} /$ sample), in quadruplicate, and these RNA extracts were submitted to RT-PCR.

\section{RESULTS}

Amplicons having 290 bp, the expected size, were obtained by RT-PCR for Piry, Indiana 3-Alagoas, Carajás, and Indiana 2-Cocal viruses, as shown in Fig. 1A. These amplicons were sequenced and aligned showing for Piry virus a $97 \%$ homology with the $\mathrm{G}$ genus nucleotide sequence of the same virus (Gen Bank D26175). Carajás and Indiana 3-Alagoas viruses were not previously sequenced and showed 85.2 and $80.6 \%$ homology rates, respectively, with the Piry virus amplicon. These high homologies with Piry virus confirm the viral origin of the amplicons. The amplicon nucleotide sequences of Piry, Indiana 3-Alagoas, and Carajás viruses were also aligned in order to select 
the Piry internal primers in high homology regions for the nested-PCR. The nested-PCR with Piry primers produced amplicons having the expected size, $\sim 130 \mathrm{bp}$, as shown in Fig. 1B.

The genome of Indiana 3-Alagoas virus was detected in the 10 clinical samples of guinea pig (blood and tarsal pad epithelial lesions tissue), and amplicons were also obtained by nested-PCR confirming the result of the RTPCR, as shown in Fig. 2.

The titer of the Piry virus seed in Vero E- 6 cells was $10^{7,82} \mathrm{TCID} 50 / \mathrm{ml}$. Amplicons were obtained by RT-PCR until the $10^{-10}$ dilution of the Piry virus seed, as shown in Fig. 3 .
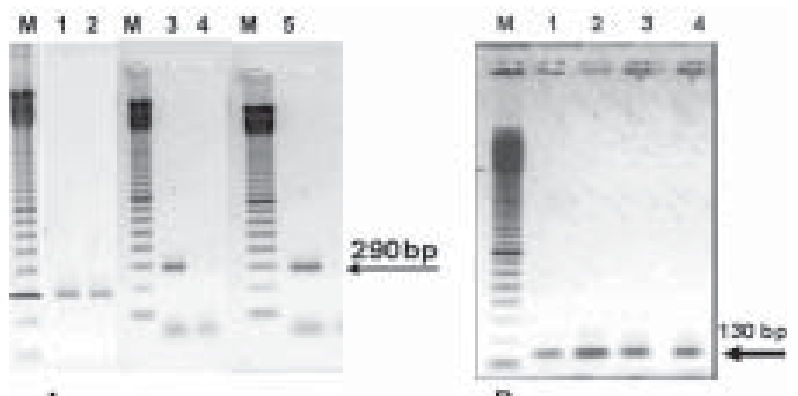

A

Fig. 1 - A: agarose gel stained with ethidium bromide showing 290 bp amplicons of a RT-PCR with Vesiculovirus G primers testing Piry (1), Carajás (2), Cocal (3) and Alagoas (5) viruses; B: it shows $130 \mathrm{bp}$ amplicons obtained in a nested-PCR with Piry primers testing Piry (1), Carajás (2), Indiana 3-Alagoas (3) and Indiana 2Cocal (4) viruses. Water was used as negative control (4) and $\mathrm{M}$ is a DNA 100bp ladder.

\section{DISCUSSION}

The RT-PCR and the nested-PCR have been used for diagnosis of vesiculovirus infections (Bilsel PA, Nichol ST 1990, Rodriguez et al. 1993, Nunez et al. 1998). In the present study we used primers (VSVG) that anneal in the G gene of Brazilian Vesiculovirus (Piry, Indiana 3-Alagoas, and Carajás) in a RT-PCR. G is a transmembrane N-glycosil protein present in the spikes of the viral surface. Thus $\mathrm{G}$ is the viral linker to cell receptors and a fundamental piece for viral endocytosis and envelope fusion to cell endossomes. $\mathrm{G}$ is also an important Vesiculovirus antigen that induces neutralizing antibodies by the infected animal (Robert \& Rose 1996). The G gene of Vesiculovirus has a variable nucleotide sequence but as is it was possible to find high homology regions in the $G$ genus for primer selection.

The use of primers that anneal in the G gene for diagnosis has not been previously reported. However, Vesiculovirus $\mathrm{G}$ primers allowed the amplification in the RT-PCR of the Brazilian Piry, Carajás, Indiana 2-Cocal, and Indiana 3-Alagoas viruses. The amplified products were sequenced and had the viral origin confirmed. The previously unknown sequences of Indiana 3-Alagoas and Carajás virus were registered in the GenBank (AY335184 and AY335185, respectively).

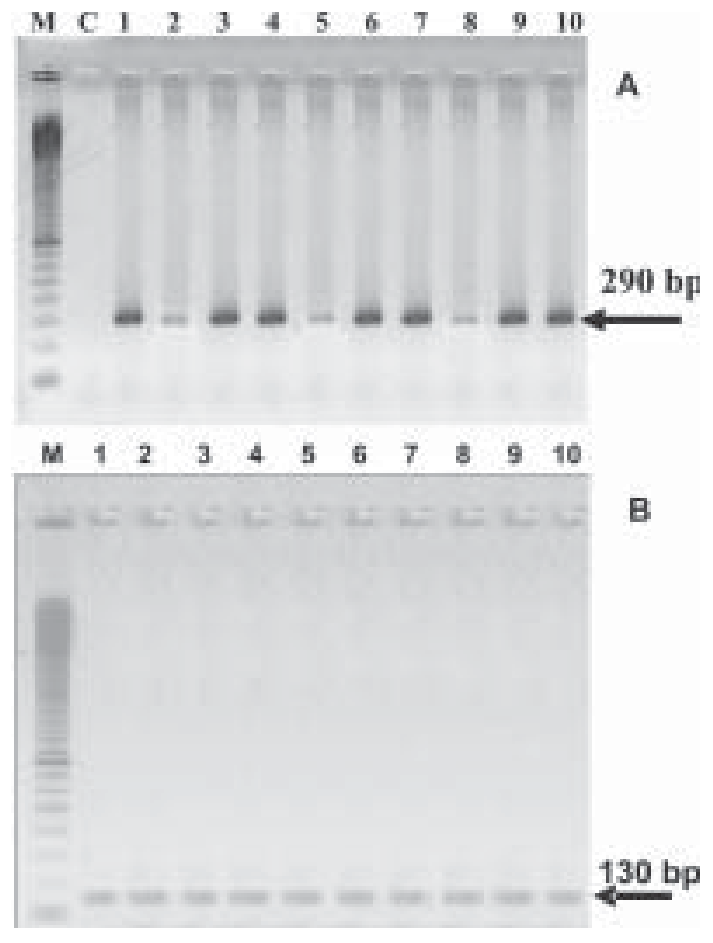

Fig. 2 - A: agarose gel stained with ethidium bromide of RT-PCR with Vesiculovirus $\mathrm{G}$ primers testing clinical samples of Guinea pig infected with Indiana 3-Alagoas virus. Lines 1 to 5 include RNA extracts of epithelial tissues from the tarsal pad of 5 animals collected 3 days after virus inoculation and lines 5 to 10 include RNA extracts of blood samples of the same animals; B: agarose gel stained with ethidium bromide of nested-PCR with Piry internal primers testing clinical samples of Guinea pig infected with Indiana 3 - Alagoas virus. Lines 1 to 5 include RNA extracts of epithelial tissues from the tarsal pad of 5 animals collected 3 days after virus inoculation and lines 5 to 10 include RNA extracts of blood samples of the same animals. M is a 100 bp DNA ladder.

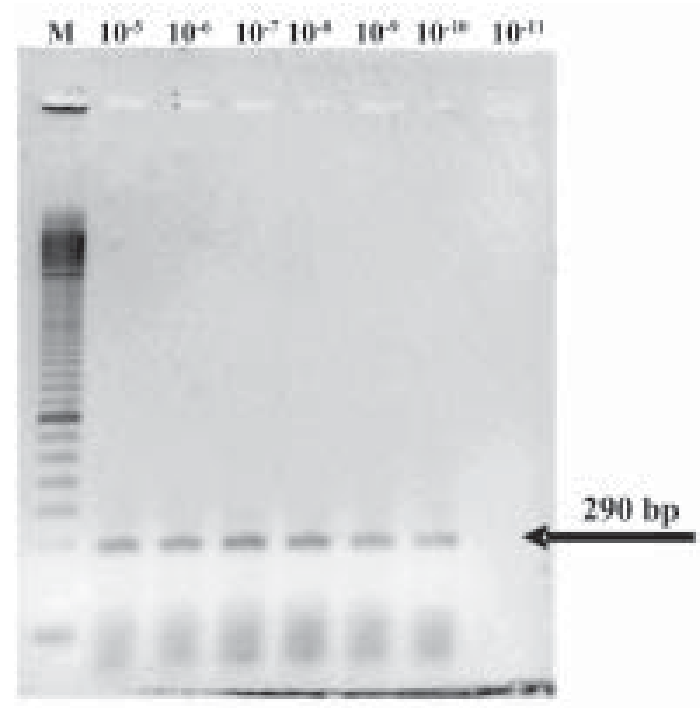

Fig. 3: agarose gel stained with ethidium bromide of the RT-PCR with Vesiculovirus $\mathrm{G}$ primers testing ten fold dilutions of an Alagoas virus sample. The test was able to amplify the virus genome (290 bp amplicons) until the $10^{-10}$ dilution.. $\mathrm{M}$ is a 100 bp DNA ladder. 
The diagnosis of Piry virus infection in Vero E6 cells using the RT-PCR was 151 times more sensitive $(2.18 \mathrm{log})$ than that based on the detection of cytophatic effect. The RT-PCR was able to detect Piry virus when the sample was diluted 10 billion times $\left(10^{-10}\right)$. It indicates that this RT-PCR for Piry virus is a highly sensitive method.

The nested-PCR was developed for confirmation of the RT-PCR results. The selected internal primers were able to amplify the genome of the four Brazilian Vesiculovirus, Piry, Indiana 3-Alagoas, Indiana 2-Cocal and Carajás.

The genome of Indiana 3-Alagoas virus was amplified from the clinical samples of infected guinea pig, detecting viremia and virus presence in the animal tarsal pad epithelial samples. Therefore this RT-nested-PCR could be used for diagnosis of VS acute infection in domestic animals since on several occasions serologic survey and virus isolation, revealed the presence of the SV virus in horse and cattles in Brazil (Federer et al. 1966, Andrade et al. 1974). Carajás and Marabá virus and specially Piry virus are also common causatives of human infection in Brazil. Serologic surveys carried out in Northeastern and Southeastern inland towns in Brazil showed that 16 and $14.3 \%$ of the participants had neutralizing antibodies to Piry virus, respectively (Figueiredo et al. 1985). Knowing that Piry infections are common and that Piry fever is probably under reported because only 3 human cases were described, this RT-PCR could be used for diagnosis of infections by this virus in Brazilian patients having acute febrile illness. Virus identification could be done by nucleotide sequencing of the amplicons.

\section{REFERENCES}

Andrade CM 1974. Estomatite Vesicular no Brasil, Thesis, Universidade Federal do Rio de Janeiro, Rio de Janeiro, $86 \mathrm{pp}$.

Arbeláez G 1983. Ensayos sobre la patogenia del virus de la estomatitis vesicular New Jersey en bovinos. Rev Inst Colombiano Agrop 18: 319-327.

Bhatt PN, Rodriguez FM 1967. Chandipura: new arbovirus isolated in India from patients with febrile illness. Indian J Med Res 55: 1295-1305.

Bilsel PA, Nichol ST 1990. Polymerase errors accumulating during natural evolution of the glycoprotein gene of vesicular stomatitis virus Indiana serotype isolates. $J$ Virol 64: 4873-4883.

Federer KE, Burrows R, Brooksby JB 1967. Vesicular stomatitis virus - Relationship between some strains of the Indiana serotype. Res Vet Sci 8: 103-117.

Fernandez AA 1986. Manual de diagnóstico de laboratorio de las enfermedades vesiculares. Centro Panamericano de Fiebre Aftosa/ Organización Panamericana de la Salud, Serie Manuales Didácticos, Rio de Janeiro, no. 15, 51 pp.

Fernandez PJ 1988. Application of Monoclonal Antibodies in Indirect Immunofluorescence for Diagnostic Subtyping of
Vesicular Stomatitis (Indiana serotype), Thesis, Yale University, New Haven, 53 pp.

Figueiredo LTM 1990. Uso de células de Aedes alpopictus C6/ 36 na propagação e classificação de arbovírus das famílias Togaviridae, Bunyaviridadae, Flaviviridae e Rhabdoviridae. Rev Soc Bras Med Trop 23: 13-18.

Figueiredo LTM, Travassos da Rosa APA, Fiorillo AM 1985. Prevalência de anticorpos neutralizantes para arbovirus Piry em indivíduos da região de Ribeirão Preto, estado de São Paulo. Rev Inst Med Trop São Paulo 27: 157-161.

Jonkers AH, Shope RE, Aitken THG, Spence L 1964. Cocal virus, a new agent in Trinidad related to vesicular stomatitis virus. Amer J Vet Res 25: 236-242.

Karabatsos N 1985. International Catalogue of Arboviruses Incluing Certain other Viruses of Vertebrates, 3th ed., American Society of Tropical Medicine and Hygiene, San Antonio, $1500 \mathrm{pp}$.

Murphy F.A, Fauquet C.M, Bishop D.H.L, Ghabrial S.A, Jarvis A.W, Martelli G.P, Mayo M.A, Summers MD 1995. Virus taxonomy. Arch Virol 140: 275-288.

Nunez JI, Blanco E, Hernandez T, Tejedor CG, Martin MJ, Dopazo J, Sobrino F 1998. RT-PCR assay for the differential diagnosis of vesicular viral deseases of swine. $J$ Virol Methods 72: 227-235.

Pirazzi G, Caggiano AJ, Alonso CH, Fernandez A 1963. Publicación Tecnica No 2, CANEFA, Ministry of Agriculture of Argentina, Buenos Aires, $110 \mathrm{pp}$.

Reed LJ, Muench H 1938. A simple method of estomating fifty per cent endpoints. Am J Hyg 27: 493-497.

Robert R, Rose WJK 1996. Rhabdoviridae: The viruses and their replication. In DM Knipe, OM Howley (eds), Fields Virology, Raven Publisher, Philadelphia, p. 561-574.

Rodriguez LL, Letchworth GJ, Spiropoulou CF, Nichols S 1993. Rapid detection of vesicular stomatitis virus New Jersey serotype in clinical samples by using polymerase chain reaction. J Clin Microbiol 31: 2016-2020.

Tavares Neto J 1992. Estudo Soro-epidemiológico do Vesiculovirus Piry na População e entre os Membros das Famílias Nucleares, em Catôlandia-Bahia, Thesis, Universidade de São Paulo, Ribeirão Preto, 254 pp.

Tesh R, Saidi S, Javadian E, Nadim AL 1977. Isfahan vírus, a new vesiculovirus infecting humans, gerbils, and sandflies in Iran. Am J Trop Med Hyg 26: 299-306.

Travassos da Rosa APA, Tesh RB, Travassos da Rosa JF, Herve JP, Main Jr AJ 1984. Carajás and Marabá viruses, two new vesiculoviruses isolated from phebotomine sand flies in Brazil. Am J Trop Med Hyg 33: 999-1006.

Vernon SD, Webb PA 1985. Recent vesicular stomatitis virus infection detected by immunoglobin $\mathrm{M}$ antibody capture enzyme-linked immunosorbent assay. J Clin Microbiol 22: 582-586.

Wilks CR, House JA 1984. Susceptibility of various animals to the vesiculovirus Piry. J Hyg 93: 147-155. 